\title{
Active removal of inorganic phosphate from cerebrospinal fluid by the choroid plexus
}

\author{
Pedro M. Guerreiro, ${ }^{1,3}$ Amy M. Bataille, ${ }^{2}$ Sonda L. Parker, ${ }^{2}$ and J. Larry Renfro ${ }^{2,3}$ \\ ${ }^{1}$ Centre of Marine Sciences, Universidade do Algarve, Faro, Portugal; ${ }^{2}$ Department of Physiology and Neurobiology, \\ University of Connecticut, Storrs, Connecticut; and ${ }^{3}$ Mount Desert Island Biological Laboratory, Salisbury Cove, Maine
}

Submitted 14 August 2013; accepted in final form 8 April 2014

\begin{abstract}
Guerreiro PM, Bataille AM, Parker SL, Renfro JL. Active removal of inorganic phosphate from cerebrospinal fluid by the choroid plexus. Am J Physiol Renal Physiol 306: F1275-F1284, 2014. First published April 16, 2014; doi:10.1152/ajprenal.00458.2013.The $\mathrm{P}_{\mathrm{i}}$ concentration of mammalian cerebrospinal fluid (CSF) is about one-half that of plasma, a phenomenon also shown here in the spiny dogfish, Squalus acanthias. The objective of the present study was to characterize the possible role of the choroid plexus (CP) in determining CSF $\mathrm{P}_{\mathrm{i}}$ concentration. The large sheet-like fourth $\mathrm{CP}$ of the shark was mounted in Ussing chambers where unidirectional ${ }^{33} \mathrm{P}_{\mathrm{i}}$ fluxes revealed potent active transport from CSF to the blood side under short-circuited conditions. The flux ratio was $8: 1$ with an average transepithelial resistance of $87 \pm 17.9 \Omega \cdot \mathrm{cm}^{2}$ and electrical potential difference of $+0.9 \pm 0.17 \mathrm{mV}$ (CSF side positive). Active $\mathrm{P}_{\mathrm{i}}$ absorption from CSF was inhibited by $10 \mathrm{mM}$ arsenate, $0.2 \mathrm{mM}$ ouabain, $\mathrm{Na}^{+}$-free medium, and increasing the $\mathrm{K}^{+}$concentration from 5 to 100 $\mathrm{mM} . \mathrm{Li}^{+}$stimulated transport twofold compared with $\mathrm{Na}^{+}$-free medium. Phosphonoformic acid $(1 \mathrm{mM})$ had no effect on active $\mathrm{P}_{\mathrm{i}}$ transport. RT-PCR revealed both $\mathrm{P}_{\mathrm{i}}$ transporter (PiT)1 and PiT2 (SLC20 family) gene expression, but no $\mathrm{Na}^{+}-\mathrm{P}_{\mathrm{i}}$ cotransporter II (SLC34 family) expression, in the shark CP. PiT2 immunoreactivity was shown by immunoblot analysis and localized by immunohistochemistry in (or near) the $\mathrm{CP}$ apical microvillar membranes of both the shark and rat. PiT1 appeared to be localized primarily to vascular endothelial cells. Taken together, these data indicate that the $\mathrm{CP}$ actively removes $\mathrm{P}_{\mathrm{i}}$ from CSF. This process has transport properties consistent with a PiT2, $\mathrm{Na}^{+}$-dependent transporter that is located in the apical region of the $\mathrm{CP}$ epithelium.
\end{abstract}

phosphate transport; cerebrospinal fluid composition; choroid plexus; Slc34; Slc20; inorganic phosphate transporter 1; inorganic phosphate transporter $2 ; \mathrm{Na}^{+}$-inorganic phosphate cotransporter II

THE INORGANIC PHOSPHATE CONCENTRATION ([P $\mathrm{P}]$ ) in human ventricular cerebrospinal fluid $(\mathrm{CSF})\left(\left[\mathrm{P}_{\mathrm{i}}\right]_{\mathrm{CSF}}\right)$ is maintained at $\sim 0.4 \mathrm{mM}$ compared with plasma at $\sim 1.8 \mathrm{mM}(11,16)$. How and why $\left[\mathrm{P}_{\mathrm{i}}\right]_{\mathrm{CSF}}$ is controlled at this lower concentration is unknown. Despite the importance of $\left[\mathrm{P}_{\mathrm{i}}\right]$ for the control of normal cellular metabolic activity, extracellular and intracellular $\mathrm{pH}$ and $\left[\mathrm{Ca}^{2+}\right](8)$, characterization of $\mathrm{P}_{\mathrm{i}}$ transport by the choroid plexus (CP) seems not to have been done in any vertebrate. The $\mathrm{CP}$ forms $70-80 \%$ of the CSF and helps stabilize and regulate its composition. The blood-brain barrier (BBB) and metabolic water (20) are the apparent sources of the remaining 20-30\% of CSF. In addition to its buoying (cushioning) effect, CSF provides a buffer for brain tissues against variations in plasma composition (4). Specific epithelial transport processes selectively mediate the exchange of various

Address for reprint requests and other correspondence: J. L. Renfro, Dept. of Physiology and Neurobiology, Univ. of Connecticut, 75 N. Eagleville Rd., U3156, Torrey Life Sciences, Rm. 63A, Storrs, CT 06269-3156 (e-mail: larry.renfro@uconn.edu). substrates between plasma and brain interstitial fluid (ISF) and CSF. Together, BBB and CP membrane transporters can perform a multitude of functions including the removal of organic wastes from brain ISF and CSF while actively managing the inorganic ion composition and rate of formation of these fluids. CSF is $\sim 15$ meq higher in $\mathrm{Cl}^{-}$than plasma with only about one-half the plasma $\left[\mathrm{K}^{+}\right] \cdot\left[\mathrm{Na}^{+}\right]$and $\mathrm{pH}$ are about the same as plasma, and $\left[\mathrm{HCO}_{3}^{-}\right]$in $\mathrm{CSF}\left(\left[\mathrm{HCO}_{3}^{-}\right]_{\mathrm{CSF}}\right)$ can vary but is usually similar to or less than that of plasma (4).

The mechanism of regulation of $\left[\mathrm{P}_{\mathrm{i}}\right]_{\mathrm{CSF}}$ is unclear. Several factors leading to significant changes in $\left[\mathrm{HCO}_{3}^{-}\right]_{\mathrm{CSF}}$ and $\left[\mathrm{Cl}^{-}\right]$ in CSF evoked modifications in $\left[\mathrm{P}_{\mathrm{i}}\right]_{\mathrm{CSF}}(15,16)$. Whether these reflect direct or indirect effects over specific $\mathrm{P}_{\mathrm{i}}$ transport mechanisms was not established. The existence of a $\mathrm{P}_{\mathrm{i}} / \mathrm{HCO}_{3}^{-}$ exchange process in isolated $\mathrm{BBB}$ capillaries has been suggested $(5,6)$. ISF enters CSF by slow bulk flow and most likely travels along perivascular pathways and axon tracts. CSF may circulate and mix with ISF along these same pathways (1). Therefore, the BBB could, at least in part, contribute to the $\mathrm{P}_{\mathrm{i}}$ balance in CSF. However, these studies were not further explored, and the existence and possible relevance of such transporters have not been demonstrated in the CP. While we lack a detailed understanding of the mechanisms that mediate and modulate the establishment and maintenance of $\left[\mathrm{P}_{\mathrm{i}}\right]_{\mathrm{CSF}}$, our understanding of the major processes influencing plasma $\left[\mathrm{P}_{\mathrm{i}}\right]$ are fairly well understood and have been reviewed (see Ref. 36). To summarize, in the intestine and kidney, members of the $\mathrm{Na}^{+}-\mathrm{P}_{\mathrm{i}}$ cotransporter type II (NaPiII) family (SLC34), located in the apical membrane of enterocytes and the proximal tubule epithelium, are well-characterized carriers responsible for $\mathrm{P}_{\mathrm{i}}$ entry into epithelial cells ( $S L C 34 b$ for intestinal absorption and $S L C 34 a$ and, to a lesser extent, $S L C 34 c$ for renal reabsorption). Two other $\mathrm{Na}^{+}-\mathrm{P}_{\mathrm{i}}$ cotransporter types are known: type III (SLC20) and type I (SLC17). The latter has a low specificity for $\mathrm{P}_{\mathrm{i}}$ transport and rather more for organic anions, including glutamate. The two SLC20 family members, $\mathrm{P}_{\mathrm{i}}$ transporter (PiT)1 (SLC20A1) and PiT2 (SLC20A2), are ubiquitously expressed and thought to have mainly a cellular $\mathrm{P}_{\mathrm{i}}$ housekeeping role, but other more specific roles are emerging for these transporters.

Direct determination of the cellular mechanisms that mediate transepithelial transport of $\mathrm{P}_{\mathrm{i}}$ and other solutes across the intact mammalian blood-CSF barrier is limited by the tissue's complex morphology, relatively small size, and limited accessibility. The frond-like folds of the mammalian CP prevent direct access to the basolateral membranes of the epithelium with techniques relying on ventriculocisternal perfusion or an isolated, intact CP. In the dogfish shark, Squalus acanthias, the fourth ventricle of the brain is covered by a sheet of choroidal epithelium with shallow convolutions, which, unlike the highly 
enfolded CP of mammals, lies on the surface of the brain and can be removed and mounted in Ussing chambers. The dogfish $\mathrm{CP}$ tissue is also 25-fold larger than that of humans (as a percentage of brain weight) and has proven to be an effective means of modeling this tissue's transepithelial transport properties $(25,34,35)$.

Here, we report that spiny dogfish shark $\left[\mathrm{P}_{\mathrm{i}}\right]_{\mathrm{CSF}}$ is maintained below that of plasma, as in humans, and that this is likely due to a powerful $\mathrm{P}_{\mathrm{i}}$ transport system in the CP, active in the CSF-to-blood direction, and with PiT (Slc20)-like transport properties. We found no evidence of Slc34 (NaPiII family of $\mathrm{P}_{\mathrm{i}}$ transporters) expression in the shark CP; however, both PiT1 and PiT2 were expressed there. PiT1 appears to be located mainly in the vascular endothelium, whereas PiT2 is localized in, or in close proximity to, the apical microvillar membranes of the $\mathrm{CP}$ epithelium at the ventricular surface in both the shark and rat.

\section{MATERIALS AND METHODS}

Animals. Adult male and female spiny dogfish sharks (S. acanthias L., $\sim 2-\mathrm{kg}$ body mass) were collected from the coastal waters off Woods Hole, MA, by the Marine Biological Laboratory or off Mount Desert Island, ME, and transported to Mount Desert Island Biological Laboratory, where they were held in large $(\sim 12,000$ liter $)$ tanks of flowing seawater for 5-10 days before use. Experiments were conducted in the period from mid-July to mid-September, during which tank temperature ranged from 13 to $17^{\circ} \mathrm{C}$. Animals were decapitated, and the cranial compartment was immediately removed, flooded with ice-cold elasmobranch Ringer (ER) solution (see below and Table 1), and placed on ice. The brain was removed, and, while the brain was submerged in ice-cold sterile ER solution, the two halves of the fourth plexus were excised and cleared of extraneous tissue. Tissues were then prepared for immunoblot analysis, immunohistochemistry, or RNA extraction or mounted in Ussing chambers for measurements of transepithelial transport.

The mammalian lateral $\mathrm{CP}$ was removed from albino laboratory rats (Rattus norveigicus), which were anesthetized with isoflurane and decapitated within 10 min postmortem. The present study adhered to

Table 1. Composition of the saline solutions used for measurements of transepithelial transport

\begin{tabular}{|c|c|c|c|c|}
\hline & \multicolumn{4}{|c|}{ ER Solutions } \\
\hline & $\begin{array}{l}\text { Regular ER } \\
\text { solution }\end{array}$ & $\begin{array}{l}\mathrm{Na}^{+} \text {-free ER } \\
\text { solution }\end{array}$ & $\begin{array}{l}\mathrm{Li}^{+} \text {-containing } \\
\text { ER solution }\end{array}$ & $\begin{array}{l}\text { High-K }{ }^{+} \text {ER } \\
\text { solution }\end{array}$ \\
\hline $\mathrm{NaCl}$ & 280 & & & 180 \\
\hline $\mathrm{LiCl}$ & & & 280 & \\
\hline $\mathrm{KCl}$ & 6 & 4 & 4 & 106 \\
\hline $\mathrm{CaCl}_{2}$ & 4 & 4 & 4 & 4 \\
\hline $\mathrm{MgCl}_{2}$ & 3 & 3 & 2.5 & 3 \\
\hline $\mathrm{NaH}_{2} \mathrm{PO}_{4}$ & 1 & & & 1 \\
\hline $\mathrm{K}_{2} \mathrm{HPO}_{4}$ & & 1 & 1 & \\
\hline $\mathrm{NaHCO}_{3}$ & 8 & & & 8 \\
\hline $\mathrm{Na}_{2} \mathrm{SO}_{4}$ & 0.5 & & & 0.5 \\
\hline $\mathrm{MgSO}_{4}$ & & 0.5 & 0.5 & \\
\hline $\begin{array}{l}N \text {-methyl-D-glucamine } \\
\text { titrated with } \mathrm{HCl}\end{array}$ & & 280 & & \\
\hline Trimethylamine & & & & \\
\hline$N$-oxide & 72 & 72 & 72 & 72 \\
\hline Urea & 350 & 350 & 350 & 350 \\
\hline HEPES & 25 & 25 & 25 & 25 \\
\hline Glucose & 5 & 5 & 5 & 5 \\
\hline $\mathrm{pH}$ adjusted to & 7.8 & 7.8 & 7.8 & 7.8 \\
\hline
\end{tabular}

Values are in mM. ER solution, elasmobranch Ringer solution. the "Guiding Principles for Research" as outlined by the American Physiological Society (2002). All investigations involving animals reported in this study were conducted in conformity with these principles. The animal protocol for sharks was approved by the Institutional Animal Care and Use Committee of Mount Desert Island Biological Laboratory (protocol no. 0606, MDIBL Institutional Assurance no. A3562-01), and the protocol for rats was approved by the Institutional Animal Care and Use Committee of the University of Connecticut (no. A11 038R).

Solutions and chemicals. ER solutions in original and modified forms $\left[\mathrm{Na}^{+}\right.$-free ER, $\mathrm{Li}^{+}$-containing $\mathrm{ER}\left(\mathrm{Li}^{+}\right.$-ER), and high- $\mathrm{K}^{+} \mathrm{ER}$ solutions] were prepared according to the specifications shown in Table 1. Saline solutions were prepared in advance and kept at $4^{\circ} \mathrm{C}$, and labile substances such as urea, trimethylamine $\mathrm{N}$-oxide, and glucose were added to the working volume just before use. For treatment with sodium arsenate $(10 \mathrm{mM})$, phosphonoformic acid (PFA; $1 \mathrm{mM})$, or ouabain $(0.2 \mathrm{mM})$, working solutions were prepared fresh each day. The protein-free nature of the ER solution closely resembled artificial elasmobranch CSF (12) and, consistent with a short-circuited state, was used on both sides of the tissue during transport measurements.

Plasma and CSF ionic composition. Blood samples were collected from the caudal vein and placed at $4^{\circ} \mathrm{C}$ until completely clotted, at which time serum was removed to a fresh tube. After animals had been decapitated, CSF was collected from the cranial cavity with a 1-ml syringe fitted with a blunted pipette tip. Both fluids were either immediately analyzed or frozen for later evaluation of cation and anion composition. $\left[\mathrm{Na}^{+}\right],\left[\mathrm{K}^{+}\right],\left[\mathrm{Mg}^{2+}\right],\left[\mathrm{Ca}^{2+}\right],\left[\mathrm{Cl}^{-}\right],\left[\mathrm{P}_{\mathrm{i}}\right]$, and $\left[\mathrm{SO}_{4}^{2-}\right]$ were determined using a Dionex DX-120 ion chromatograph.

Transepithelial $P_{i}$ transport. Excised halves of the fourth CP were mounted in Ussing chambers with an aperture size of $0.197 \mathrm{~cm}^{2}$ and fluid volume (ER solution) of $1.9 \mathrm{ml} /$ hemichamber. The temperature was maintained at a constant $14^{\circ} \mathrm{C}$, and fluid inside the chambers was constantly and vigorously stirred with small magnetic stir bars turned by external stir plates and insufflated with humidified $99 \% \quad \mathrm{O}_{2}-1 \%$ $\mathrm{CO}_{2}$. The transepithelial potential difference (TPD) was determined with $\mathrm{Ag} / \mathrm{AgCl}$ electrodes connected to the CSF and interstitial (blood side) compartments with $3 \mathrm{M} \mathrm{KCl}-2 \%$ agar bridges. Electrical properties were determined with a computer-controlled, high-impedance automatic dual-voltage clamp (DVC 4000, World Precision Instruments, Sarasota, FL). Electrode asymmetry was corrected at the beginning and end of each experiment. Short-circuiting electrodes were connected to the CSF and interstitial solutions with $3 \mathrm{M} \mathrm{KCl}-2 \%$ agar bridges. The transepithelial resistance (TER) was determined from the change in TPD produced by a brief $10-\mu \mathrm{A}$ pulse controlled by the voltage clamps. TER was corrected for fluid resistance. During flux determinations, the tissues were continuously short circuited (i.e., clamped at TPD $=0 \mathrm{mV}$ ), and the integrity of the tissues was assessed by measurements of TPD and TER at various time points during and at the end of each experiment.

Unidirectional tracer fluxes were initiated by the addition of 1.0 $\mu \mathrm{Ci} \mathrm{H}_{3}{ }^{33} \mathrm{PO}_{4}$ (MP Biomedicals) to the appropriate hemichamber. Duplicate 50- $\mu \mathrm{l}$ samples were taken from the unlabeled side at 30-min intervals over a period of $2 \mathrm{~h}$ and replaced with equal volumes of unlabeled solution. Radioactivity was measured by liquid scintillation (Packard TriCarb 2200CA). The specific activity of the labeled solution was determined at the beginning and end of each experiment. Net flux was calculated as the difference between unidirectional secretory (blood side to CSF side) and reabsorptive (CSF side to blood side) fluxes.

To determine the effects of arsenate, PFA, or ouabain on active $P_{i}$ transport, tissues in Ussing chambers were initially incubated in ER solution (with $\mathrm{H}_{3}{ }^{33} \mathrm{PO}_{4}$ added to the CSF side) for 60 min to establish basal transport, and this solution was then removed and replaced with ER solution containing the appropriate inhibitor at the described concentrations. Isotope was added to the CSF side, and transport was measured for $60 \mathrm{~min}$. To establish the roles of $\mathrm{Na}^{+}$and $\mathrm{Li}^{+}$, transport 
was initially measured in $\mathrm{Na}^{+}$-free ER solution for $60 \mathrm{~min}$; the tissue was then rinsed, and $\mathrm{Li}^{+}$-ER solution was added for $60 \mathrm{~min}$ followed by a rinse and the addition of normal $\mathrm{Na}^{+}$-containing ER solution for an additional $60 \mathrm{~min}$. To determine the effects of changing the plasma membrane $\mathrm{K}^{+}$gradient, transport was measured in control ER solution for $60 \mathrm{~min}$, and the solution was then replaced with high- $\mathrm{K}^{+} \mathrm{ER}$ solution for an additional 60-min measurement. To establish whether this effect was reversible, some tissues were then returned to control ER solution for an additional 60-min flux measurement. Control flux measurements were done by changing solutions as described above using only control ER solution.

Isolation of mRNA and RT-PCR. Freshly isolated tissues were collected into RNAlater (Sigma) and stored at $4{ }^{\circ} \mathrm{C}$ until further processed. RNA was isolated from tissues using the Qiagen RNeasy kit according to the manufacturer's instructions. RNA concentrations and purity were measured at 260 and $280 \mathrm{~nm}$ using a UV Nanodrop spectrophotometer (Thermo Scientific) to ensure the same total RNA from each tissue per reaction. Synthesis of cDNA and semiquantitative PCR were performed using the Qiagen OneStep RT-PCR kit, and primers were generated (Integrated DNA Technologies) against the partial sequences for spiny dogfish shark NaPiII, PiT1, and PiT2 retrieved from MDIBL expressed sequence tags (for primer sequences and respective GenBank Accession Numbers, see Table 2). The RT reaction was performed at $50^{\circ} \mathrm{C}$ for $30 \mathrm{~min}$ followed by $95^{\circ} \mathrm{C}$ incubation for $15 \mathrm{~min}$ to denature the reverse transcriptase. This was immediately followed by the PCR, which had a denaturing temperature of $94^{\circ} \mathrm{C}$ for $1 \mathrm{~min}$, an annealing temperature of $54^{\circ} \mathrm{C}$ for $1 \mathrm{~min}$, and an extending temperature of $72^{\circ} \mathrm{C}$ for $1 \mathrm{~min}$ for 30 cycles. Identical amounts of PCR products were separated on a $1 \%$ agarose gel and stained with Gel-Star (Lonza Rockland, Rockland, ME).

Immunolocalization. Immunohistochemistry of PiT1 and PiT2 was done with polyclonal rabbit anti-human antibodies (PiT1: sc-98814, Santa Cruz Biotechnology; PiT2: HPA026540, Sigma-Aldrich) diluted 1:1,600 and 1:1,000, respectively. Shark fourth CPs were fixed in $10 \%$ formalin and paraffin embedded. Five-micrometer sections were quenched with $3 \% \mathrm{H}_{2} \mathrm{O}_{2}$ for $10 \mathrm{~min}$ (PiT2) or $30 \mathrm{~min}$ (PiT1). Antigen retrieval for PiT2 was done with Target Retrieval Solution (Dako) for $20 \mathrm{~min}$ in steam. PiT1 antigen retrieval was done by treatment with Dako's Proteinase K solution for $10 \mathrm{~min}$. After blockade with Animal-Free Block solution (Vector), primary antibody exposure was done for $60 \mathrm{~min}$ (PiT2) or overnight (PiT1). In all cases, the secondary antibody was Dako's Envision + Dual Link Polymer (catalog. no. K4063) exposure for $30 \mathrm{~min}$. Chromogen was nova red (SK-4800, Vector) applied for $10 \mathrm{~min}$ and counterstained with hematoxylin. Isotype controls were treated with nonimmune rabbit IgG instead of primary antibody.

Immunohistochemistry of PiT2 in the rat lateral CP was done with a goat anti-human antibody (sc-50274, Santa Cruz Biothechnology) and fivefold excess blocking peptide (sc-50274P, Santa Cruz Biothechnology). Rat tissues were prepared for immunohistochemistry as described above.

Protein isolation, SDS-PAGE, and immunoblot analysis. CPs were placed in sample buffer $(2.3 \%$ SDS, $5 \% \quad \beta$-mercaptoethanol, $10 \%$ glycerol, $0.5 \%$ bromophenol blue, and $62.5 \mathrm{mM}$ Tris. $\mathrm{HCl}, \mathrm{pH} 6.8$ ) containing a mixture of protease inhibitors, vortexed vigorously, and centrifuged. The supernatant was collected and used for SDS-PAGE (12\% resolving gel, $4 \%$ stacking gel). Gel products were transferred to a polyvinylidene fluoride (PVDF) membrane (Millipore). PVDF membranes were treated with blocking buffer (PBS containing 137 $\mathrm{mM} \mathrm{NaCl}, 2.7 \mathrm{mM} \mathrm{KCl}, 4.3 \mathrm{mM} \mathrm{Na}_{2} \mathrm{HPO}_{4}$, and $1.5 \mathrm{mM} \mathrm{KH}_{2} \mathrm{PO}_{4}, \mathrm{pH}$ 7.3 with $\mathrm{HCl}$ ) with $3 \%$ nonfat dry milk and $0.05 \%$ Tween 20 for $2 \mathrm{~h}$ at room temperature. Spiny dogfish shark PiT2 was detected using an affinity-purified polyclonal rabbit anti-rat antibody (kindly provided by Dr. Victor Sorribas, University of Zaragoza, Zaragoza, Spain) diluted 1:500 and a rabbit anti-human polyclonal antibody (SLC20A2, HPA026540, Sigma-Aldrich) diluted 1:500. Rat lateral CP PiT2 was detected with the antibody provided by Dr. Sorribas as described above and with a commercially available goat anti-human antibody (sc-50274 and blocking peptide sc-50274P, Santa Cruz Biotechnology) diluted 1:500. $\beta$-Actin was detected with a commercially available affinity-purified polyclonal rabbit anti- $\beta$-actin antibody diluted 1:1,000 (Sigma) (30). PVDF membranes were incubated in the PBSdry milk-Tween 20 solution containing the primary antibodies at $4^{\circ} \mathrm{C}$ for $1 \mathrm{~h}$ ( $\beta$-actin) or overnight (PiT2), washed three times for $10 \mathrm{~min}$ in the PBS-dry milk-Tween 20 solution, and incubated with secondary goat anti-rabbit (Sigma) or donkey anti-goat (Santa Cruz, sc2020) IgG peroxidase conjugate diluted 1:2,000 and 1:5,000, respectively, in the PBS-dry milk-Tween 20 solution for $1 \mathrm{~h}$ at room temperature. Membranes were washed three times for $10 \mathrm{~min}$ in the PBS-dry milkTween 20 solution and then rinsed twice with PBS. Signals were detected using ECL Western blotting reagents (Pierce) according to the manufacturer's instructions and developed on X-ray film (Fujifilm).

Statistics. Experimental results are expressed as means \pm SE of 4-7 individual tissues or fluid samples. To determine differences between the composition of plasma and CSF, a Student's $t$-test was used. For comparison between two sets of data showing transport function, the hypothesis that two values recorded in the same tissue at $60 \mathrm{~min}$ after exposure to each treatment were identical was tested using a paired $t$-test. The same method was used for the analysis of TER data. Values were considered different at a 95\% confidence level. Statistical analyses were done using SigmaStat 3.0 (SYSTAT Software).

\section{RESULTS}

Plasma and CSF composition. The concentrations of several inorganic components of shark serum and CSF are shown in Table 3. CSF taken from the fourth ventricle and serum from the caudal hemal vein blood was no different in cation or sulfate concentrations. Very significant differences in the two fluids were apparent in $\left[\mathrm{Cl}^{-}\right]$and $\left[\mathrm{P}_{\mathrm{i}}\right]$. As in mammals, $\left[\mathrm{Cl}^{-}\right]$ was $\sim 15 \mathrm{mM}$ higher in $\mathrm{CSF}$, and $\left[\mathrm{P}_{\mathrm{i}}\right]_{\mathrm{CSF}}$ was about one-half that of serum.

Table 2. Primer sequences used for the amplification of NaPiII, PiT1, and PiT2 from dogfish shark tissues

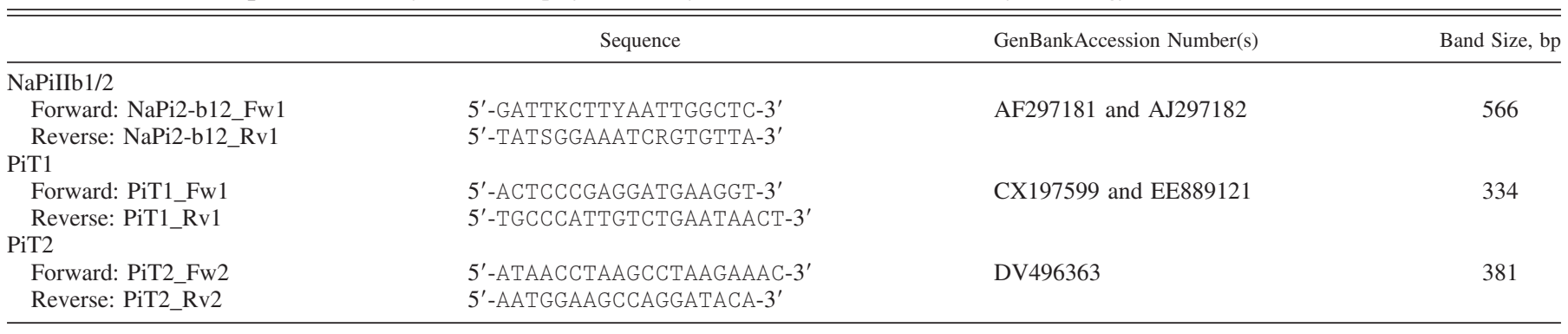

$\mathrm{NaPiII}, \mathrm{Na}^{+}-\mathrm{P}_{\mathrm{i}}$ cotransporter II; PiT, $\mathrm{P}_{\mathrm{i}}$ transporter. 
Table 3. Comparison of the ionic composition of serum and cerebrospinal fluid in the spiny dogfish

\begin{tabular}{lcc}
\hline \hline Component & Serum & Cerebrospinal Fluid \\
\hline Major cations & & \\
$\quad$ Sodium & $270 \pm 3.8$ & $275 \pm 4.5$ \\
Potassium & $2.7 \pm 0.36$ & $2.7 \pm 0.10$ \\
Magnesium & $1.4 \pm 0.15$ & $1.6 \pm 0.13$ \\
$\quad$ Calcium & $5.2 \pm 0.17$ & $5.2 \pm 0.12$ \\
Major anions & & \\
$\quad$ Chloride & $240 \pm 5.2$ & $254 \pm 2.9 \dagger$ \\
Phosphate & $1.3 \pm 0.33$ & $0.6 \pm 0.11^{*}$ \\
Sulfate & $0.5 \pm 0.20$ & $0.4 \pm 0.16$ \\
\hline
\end{tabular}

Values (in $\mathrm{mM}$ ) are means \pm SE; $n=6-8$. Significant differences from serum at $* P<0.05$ and $\dagger P<0.001$, respectively.

Unidirectional $P_{i}$ fluxes. With transepithelial voltage $(+0.9 \pm$ $0.17 \mathrm{mV}$, sign refers to the ventricular side) clamped at zero and identical ER solution on each side, ${ }^{33} \mathrm{P}$-labeled $\mathrm{P}_{\mathrm{i}}$ unidirectional fluxes across the freshly dissected dogfish shark fourth $\mathrm{CP}$ were measured. The summary of a few time courses (Fig. 1) showed that while transepithelial transport in the blood-to-CSF direction was low and rather homogeneous, CSF-to-blood fluxes were much greater and somewhat more variable between preparations from individual animals. In most preparations, steady-state $P_{i}$ flux was achieved within $30 \mathrm{~min}$ after the addition of ${ }^{33} \mathrm{P}_{\mathrm{i}}$, and, although typical experiments lasted only $2 \mathrm{~h}$, the tissues maintained stable transport rates for at least $4 \mathrm{~h}$ (data not shown). The magnitude of the fluxes in the CSF-to-blood direction averaged approximately eight times that measured in the opposite direction, but, in some cases, flux ratios of up to 30:1 were observed. The two halves of the same fourth $\mathrm{CP}$ generally had very similar TER; however, preparations from different individuals varied somewhat more (86.6 \pm $17.9 \Omega \cdot \mathrm{cm}^{2}$ for the tissues shown in Fig. 1).

The transport properties of the prominent members of Slc34 and $S l c 20$ in the gut and renal tubule have been determined in heterologous expression systems (see Ref. 36). Three members of the Slc34 family, NaPiIIa and NaPiIIc in the renal proximal tubule and $\mathrm{NaPiIIb}$ in the duodenum and jejunum, together with two members of the Slc20 family, PiT1 and PiT2, have been compared. These reported functional properties were used here to partially characterize the $\mathrm{CP}$ active $\mathrm{P}_{\mathrm{i}}$ transport process.

Effects of arsenate and PFA. Incubation of tissues with the $P_{i}$ mimetic arsenate $(10 \mathrm{mM})$ for 60 min clearly reduced $P_{i}$ transport across the CP (Fig. 2A). Fluxes were reduced from $49.9 \pm 3.10$ to $10.9 \pm 1.11 \mathrm{nmol} \cdot \mathrm{h}^{-1} \cdot \mathrm{cm}^{-2}$, roughly a fivefold reduction, but no significant change was observed in TER $\left(71.0 \pm 4.77\right.$ and $66.3 \pm 5.45 \Omega \cdot \mathrm{cm}^{2}$ for control and arsenatetreated periods, respectively). Treatment with PFA, however, had no significant effect on $\mathrm{P}_{\mathrm{i}}$ transport (Fig. 2B) or TER. During the control and PFA treatment periods, mean fluxes and TER were $35.5 \pm 13.21 \mathrm{nmol} \cdot \mathrm{h}^{-1} \cdot \mathrm{cm}^{-2}$ and $77.4 \pm 13.91$ $\Omega \cdot \mathrm{cm}^{2}$ and $45.5 \pm 14.96 \mathrm{nmol} \cdot \mathrm{h}^{-1} \cdot \mathrm{cm}^{-2}$ and $79.0 \pm 13.54$ $\Omega \cdot \mathrm{cm}^{2}$, respectively. In our laboratory, $1 \mathrm{mM}$ PFA strongly inhibited $\mathrm{P}_{\mathrm{i}}$ uptake by mouse renal proximal tubule primary cultures (30) (56.4 $\pm 1.73 \%$ of control, $n=3)$, confirming the observations of others on the effectiveness of PFA in a tissue where NaPiIIa transport predominates.

$\mathrm{Na}^{+} / \mathrm{Li}^{+}$-dependent $\mathrm{P}_{i}$ transport. Treatment of tissues with $0.2 \mathrm{mM}$ ouabain induced a 1.5-fold reduction in $\mathrm{P}_{\mathrm{i}}$ flux (Fig. $2 C$ ), but the $\mathrm{Na}^{+}-\mathrm{K}^{+}$-ATPase inhibitor had no effect on tissue
TER, which was $77.0 \pm 14.64 \Omega \cdot \mathrm{cm}^{2}$ after $60 \mathrm{~min}$ in regular ER solution and $80.6 \pm 16.94 \Omega \cdot \mathrm{cm}^{2}$ after $60 \mathrm{~min}$ in ER solution containing ouabain. In another set of tissues, substitution of regular ER solution with $\mathrm{Na}^{+}$-free ER solution greatly reduced $P_{i}$ transport from CSF to the blood side (Fig. $2 D$ ). In this series of measurements, average $\mathrm{P}_{\mathrm{i}}$ transport in $\mathrm{Na}^{+}$-free ER solution $\left(6.8 \pm 2.82 \mathrm{nmol} \cdot \mathrm{h}^{-1} \cdot \mathrm{cm}^{-2}\right)$ was roughly 4.5 -fold lower than in regular ER solution (29.7 \pm $\left.4.12 \mathrm{nmol} \cdot \mathrm{h}^{-1} \cdot \mathrm{cm}^{-2}\right)$, which was accompanied by significantly different $(P>0.004)$ TER, with recorded mean values of $56.4 \pm 5.70$ and $126.6 \pm 17.56 \Omega \cdot \mathrm{cm}^{2}$ for ER and $\mathrm{Na}^{+}$-free ER solutions, respectively.

Substitution of $\mathrm{Li}^{+}$for all of the $\mathrm{N}$-methyl-D-glucamine ${ }^{+}$in $\mathrm{Na}^{+}$-free ER solution $\left(\mathrm{Li}^{+}\right.$-ER solution) induced a significant 2.5-fold increase in $\mathrm{P}_{\mathrm{i}}$ transport by tissues previously incubated in $\mathrm{Na}^{+}$-free ER solution (from $3.9 \pm 1.11$ to $9.7 \pm 2.18$ $\mathrm{nmol} \cdot \mathrm{h}^{-1} \cdot \mathrm{cm}^{-2}$ ). When $\mathrm{Li}^{+}$-ER solution was replaced with regular $\mathrm{Na}^{+}$-containing ER solution, the $\mathrm{P}_{\mathrm{i}}$ flux further in-

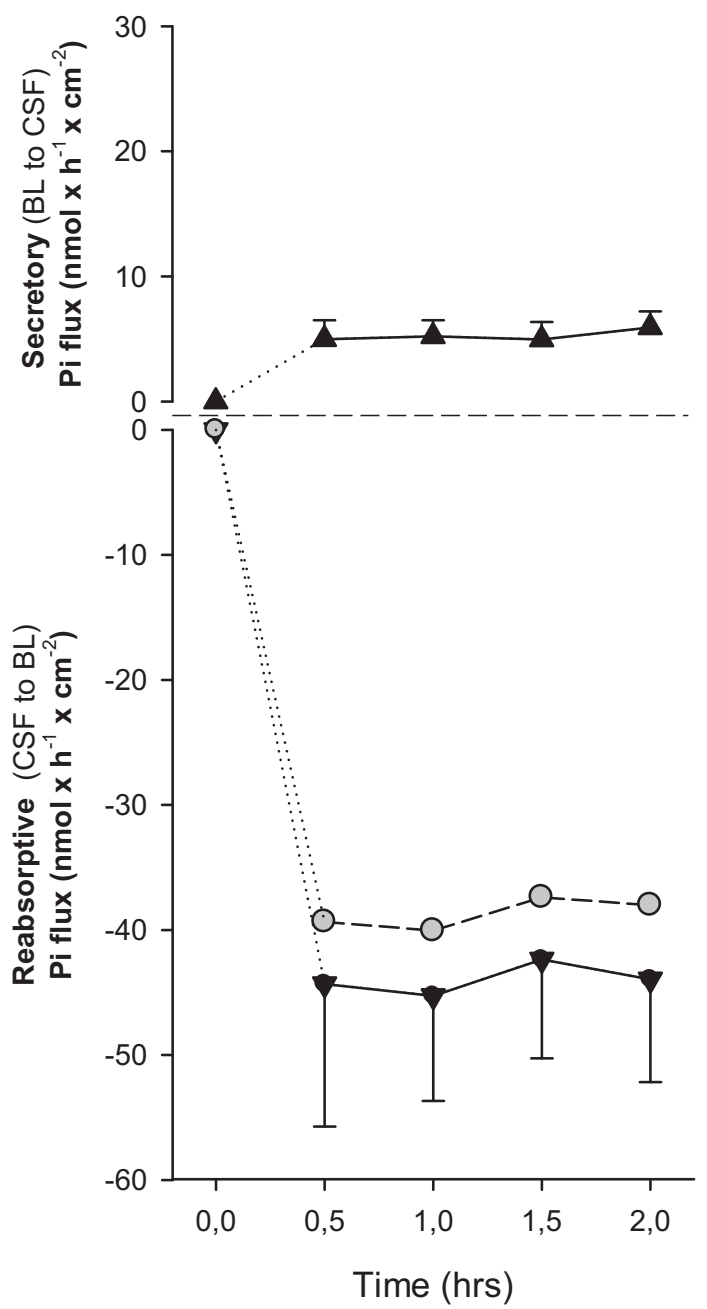

Fig. 1. Representative data showing the unidirectional [secretory: blood (BL) to cerebrospinal fluid (CSF) and reabsorptive: CSF to BL] transport (solid triangles) and net transepithelial transport (gray circles) of radiolabeled $\mathrm{P}_{\mathrm{i}}$ by the shark fourth (IVth) choroid plexus (CP) mounted in Ussing chambers and short circuited, i.e., elasmobranch Ringer (ER) solution was on both sides, and transepithelial potential difference was clamped at zero. ${ }^{33} \mathrm{P}_{\mathrm{i}}$ was added at time 0 , and steady-state flux was usually reached within 30-60 min. Data points are means $\pm \mathrm{SE} ; n=4$. 

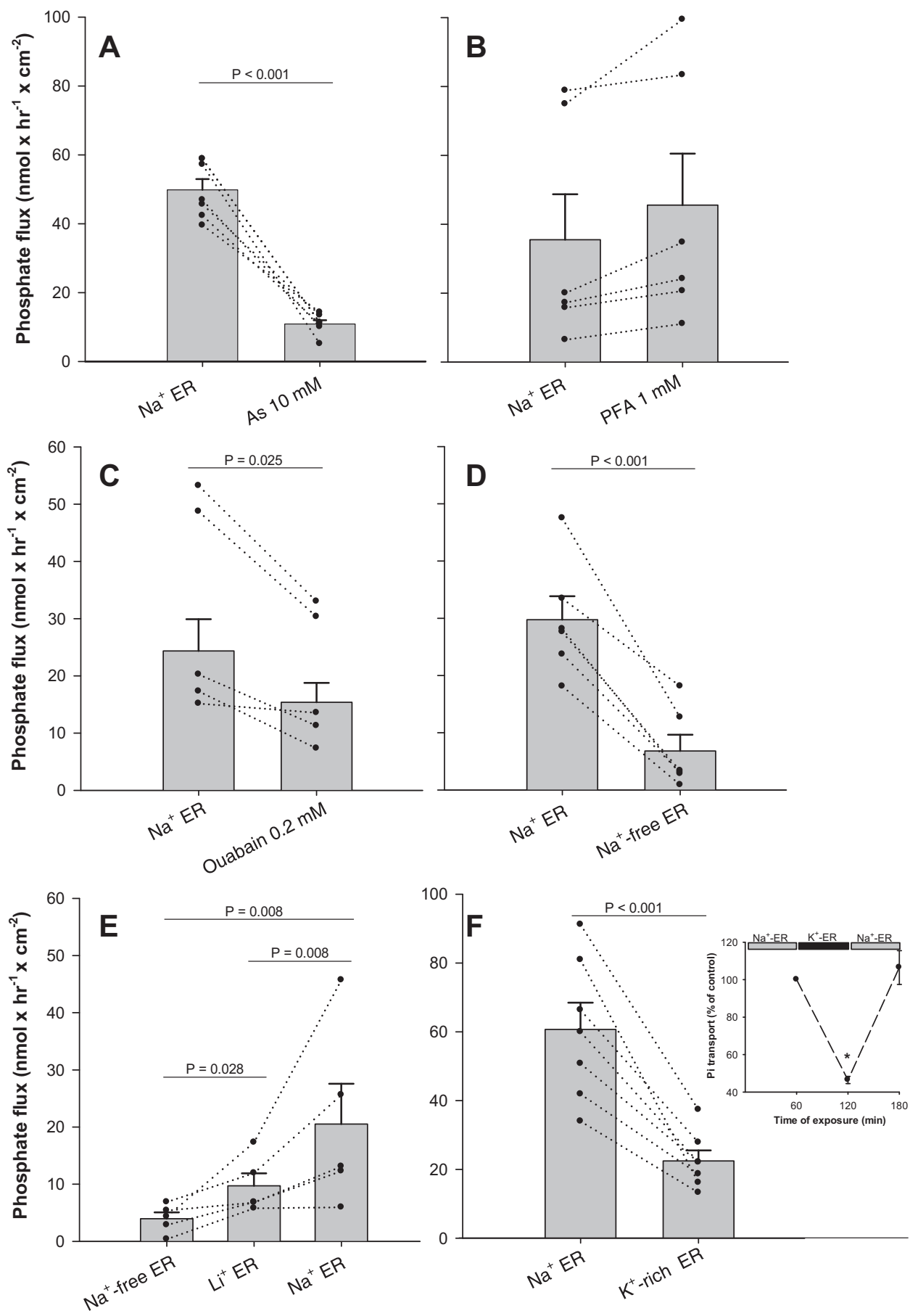

Fig. 2. Effects of two classical inhibitors of $P_{i}$ transport and treatments altering $\mathrm{Na}^{+}$and $\mathrm{K}^{+}$ plasma membrane gradients on net transepithelial transport across the isolated shark IVth CP. A: tissues were exposed (on both CSF and BL sides) to standard ER solution for $60 \mathrm{~min}$ and then to the same solution containing sodium arsenate for another 60 $\min (n=6) . B$ : in a similar experiment, tissues initially exposed to ER solution for 60 min were subsequently treated with $1 \mathrm{mM}$ phosphonoformic acid (PFA; $n=6$ ). $C$ : tissues were exposed (on both CSF and BL sides) to standard $\mathrm{Na}^{+}$-containing ER solution for $60 \mathrm{~min}$ with a subsequent exposure to the same solution containing $0.2 \mathrm{mM}$ ouabain $(n=6)$. $D$ : tissues were bathed in $\mathrm{Na}^{+}$containing ER solution for $60 \mathrm{~min}$ followed by an exposure to $\mathrm{Na}^{+}$-free ER solution for $60 \min (n=6) . E: \mathrm{P}_{\mathrm{i}}$ transport by the isolated shark IVth CP exposed (on both CSF and BL sides) to $\mathrm{Na}^{+}$-free ER soltuion (with $280 \mathrm{mM}$ $\mathrm{N}$-methyl-D-glucamine) for $60 \mathrm{~min}$, to $\mathrm{Li}^{+}$containing ER solution $(280 \mathrm{mM} \mathrm{LiCl})$ for 60 $\mathrm{min}$, and then to standard $\mathrm{Na}^{+}$-containing ER solution $(280 \mathrm{mM} \mathrm{NaCl})$ for another $60 \mathrm{~min}$ $(n=5) . F$ : the shark IVth CP was exposed (on both CSF and BL sides) to standard ER solution for $60 \mathrm{~min}$ and then to $\mathrm{K}^{+}$-enriched ER solution $(100 \mathrm{mM} \mathrm{KCl}$ substituted for $100 \mathrm{mM} \mathrm{NaCl})$ for another $60 \mathrm{~min}(n=7)$. Inset: plot demonstrating that the tissue transport capability was not permanently compromised by high $\mathrm{K}^{+}(n=4)$. *Significantly different from control $(P<0.01)$. Data are means \pm SE. Solid circles connected by dotted lines show changes in transport rates for individual preparations before and after exposure to the respective solution. creased to $20.5 \pm 7.06 \mathrm{nmol} \cdot \mathrm{h}^{-1} \cdot \mathrm{cm}^{-2}$, more than twice that observed in $\mathrm{Li}^{+}$-ER solution and about five times higher than in $\mathrm{Na}^{+}$-free ER solution (Fig. 2E). TERs in these tissues averaged $139.9 \pm 19.74 \Omega \cdot \mathrm{cm}^{2}$ in $\mathrm{Na}^{+}$-free ER solution, $93.0 \pm 20.34 \Omega \cdot \mathrm{cm}^{2}$ in $\mathrm{Li}^{+}$-ER solution, and $70.8 \pm 20.50$ $\Omega \cdot \mathrm{cm}^{2}$ in regular ER solution. The differences among treatments were all statistically significant on a paired basis $(P<$ 0.001).

$\mathrm{K}^{+}$gradient dependence. Substitution of ER solution with $\mathrm{K}^{+}$-rich ER solution $\left(\sim 100 \mathrm{mM} \mathrm{K} \mathrm{K}^{+}\right)$resulted in an approximately threefold decrease in the $\mathrm{P}_{\mathrm{i}}$ transport rate (Fig. $2 F$ ). These changes (from $60.7 \pm 7.77$ to $22.5 \pm 3.05 \mathrm{nmol} \cdot \mathrm{h}^{-1} \cdot \mathrm{cm}^{-2}$ ) were not caused by changes in TER, which averaged $48.7 \pm 3.35$ and $43.0 \pm 3.42 \Omega \cdot \mathrm{cm}^{2}$ for ER and $\mathrm{K}^{+}$-rich ER solutions, respectively. In experiments aimed to evaluate the reversibility of this effect, when $\mathrm{K}^{+}$-rich ER solution was removed and tissues were incubated with regular ER solution again for an additional $60 \mathrm{~min}$, the $\mathrm{P}_{\mathrm{i}}$ flux recovered to the initial level (see Fig. $2 F$, inset). $\mathrm{K}^{+}$ was increased by substituting $100 \mathrm{mM} \mathrm{K}^{+}$for $100 \mathrm{mM} \mathrm{Na}^{+}$, and it should be noted that the remaining $\mathrm{Na}^{+}$of $180 \mathrm{mM}$ is well above the saturating concentration for mammalian PiT2 expressed in Xenopus oocytes (26).

$P_{i}$ transporter expression and localization. Data "mining" of the MDIBL $S$. acanthias expressed sequence tag database 
(DeCypher.MDIBL.org) identified several partial DNA sequences that showed considerable conservation with zebrafish (Danio rerio, NP_997753, NP_998344 and NP_001071014), green pufferfish (Tetraodon negroviridis, CAG08601), African clawed frogs (Xenopus laevis, NP_001083287 and NP 001088186), rats (R. norvegicus, NP_112410 and NP_058919), and humans (Homo sapiens, NP_005406 and NP_006740.1) PiT1 and PiT2 proteins. Two of these sequences corresponded to 76 (PiT1) and 100 (PiT2) amino acids in a very conserved region near the $\mathrm{NH}_{2}$-terminus, encompassing the extracellular domain and first and second transmembrane domains, the first (intracellular) loop and extending into part of the second (extracellular) loop (PiT1), and the third transmembrane domain (PiT2). These sequences shared $72 \%$ nucleotide and $82 \%$ protein identity and cluster differently with PiT1 and PiT2. A third fragment was found with a high correspondence to a 232amino acid region that spans from approximately half of the seventh loop (intracellular) to the tenth loop (extracellular), thus comprising transmembrane domains seven, eight, and nine. This sequence shared considerably higher identity with the amino acid sequence of PiT1 than of PiT2 in X. laevis (72\% vs. $60 \%$ ), $R$. norvegicus ( $84 \%$ vs. $59 \%$ ), and H. sapiens ( $86 \%$ vs. $59 \%)$.

Partial DNA sequences for S. acanthias NaPiIIb (Slc34A2) can be found in the GenBank database, named as NaPillb1 and NaPillb2. These correspond to protein fragments of 230 and 290 amino acids, spanning from the end of the fourth to the beginning of the tenth transmembrane domains. The dogfish NaPillb1 fragment shares $66 \%$ identity with NaPiIIb2 and 59\% with rat NaPiIIa (Slc34Al) and $68 \%$ with rat NaPiIIb equivalent regions, whereas the dogfish $\mathrm{NaPiIIb} 2$ fragment shares $65 \%$ identity with rat NaPiIIa and $66 \%$ with rat NaPiIIb.

Electrophoresis of RT-PCR products obtained using PiT1or PiT2-specific primers (Table 2) showed bands of the expected size in the shark fourth $\mathrm{CP}$ as well as in the shark kidney (used as a positive control tissue; Fig. 3). For the RT-PCR performed using degenerate primers for NaPiII (these were designed for regions with high homology between the NaPiIIb1 and NaPiIIb2 shark sequences to detect the presence of either or both mRNA types), no bands appeared in lanes corresponding to the $\mathrm{CP}$, but bands of the expected size were present for products obtained with shark kidney cDNA.

Immunohistochemical analyses of PiT1 and PiT2 in the shark fourth CP are shown in Fig. 4. The presence of nucleated red blood cells in the vascular spaces helped to locate endothelial cells, which have flattened nuclei compared with the CP epithelium (Fig. 4A). Immunostaining revealed that PiT1 was located predominantly in vascular endothelial cells, although a weak signal may be in the basolateral membranes of the $\mathrm{CP}$ epithelium (Fig. 4C). There was no indication of PiT1 in the microvilli of the ventricular surface. The PiT1 subcellular location within the highly attenuated endothelial cells was not resolvable.

PiT2 immunostaining revealed a very clear localization of PiT2 in the shark CP epithelium (Fig. 4D). The strongest PiT2 signal was in the microvilli of the ventricular surface, although weak staining in the basolateral membranes and cytosol could not be ruled out. There was no indication of PiT2 staining in any other part of the CP. Localization of PiT2 immunostaining was the same in the rat lateral $\mathrm{CP}$ as in the shark $\mathrm{CP}$ (Fig. 5). Staining in the apical microvilli (Fig. 5A) was absent in the presence of the blocking peptide (Fig. $5 D$ ).

Shark and rat lateral CP and shark fourth CP immunoblots are shown in Fig. 6. Lanes 1 and 2 show that anti-human and anti-rat PiT2 antibodies worked equally well to reveal a distinct single band at $72 \mathrm{kDa}$ in the shark fourth $\mathrm{CP}$, which corresponds to the expected mass based on the amino acid sequence for rat PiT2. Lanes 2 and 3 show that the shark fourth CP and shark lateral $\mathrm{CP}$ had the same PiT2 signal. Lanes 4 and 5 show that the anti-rat PiT2 antibody worked equally well in shark and rat CPs. Lanes 6 and 7 confirmed the effectiveness of the blocking peptide used for immunolocalization of the PiT2 signal in the rat CP shown in Fig. 5. The presence of a band corresponding to $\beta$-actin (of $\sim 42 \mathrm{kDa}$ ) was also identified in these samples and used as a relative internal standard to control for the integrity of the protein extracts.

\section{DISCUSSION}

$\left[\mathrm{P}_{\mathrm{i}}\right]_{\mathrm{CSF}}$ of the dogfish shark was consistently lower than that of serum, and $\left[\mathrm{Cl}^{-}\right]$in CSF was higher than in serum. These characteristics are also normal in mammals, including humans $(4,16)$. The values reported here for the inorganic ion concentrations in spiny dogfish CSF are in agreement with previously reported measurements (12); however, this seems to be the first determination of $\left[\mathrm{P}_{\mathrm{i}}\right]$ and $\left[\mathrm{SO}_{4}^{2-}\right]$ in $S$. acanthias CSF. Considering the phylogenetic distance, the relationships between the concentrations of $\mathrm{Cl}^{-1}$ and phosphate in plasma and CSF are apparently very highly conserved.

The potent active transepithelial transport process in the $\mathrm{CP}$ described above likely participates in maintaining the lower $\left[\mathrm{P}_{\mathrm{i}}\right]_{\mathrm{CSF}}$. The advantageous anatomic arrangement of the fourth
Fig. 3. Gene expression of $\mathrm{P}_{\mathrm{i}}$ transporter (PiT)1 and PiT2 (Slc20) and $\mathrm{Na}^{+}-\mathrm{P}_{\mathrm{i}}$ cotransporter type IIb [NaPiIIb (NaPi-2); Slc34] in the spiny dogfish shark. A representative agarose gel is shown loaded with equal amounts of RT-PCR products from RNA extracted from the IVth shark CP and dogfish shark kidney $(\mathrm{Kd})$. There was no expression of NaPiIIb in the IVth CP. No bands were detected when the reactions were run without the RT step.
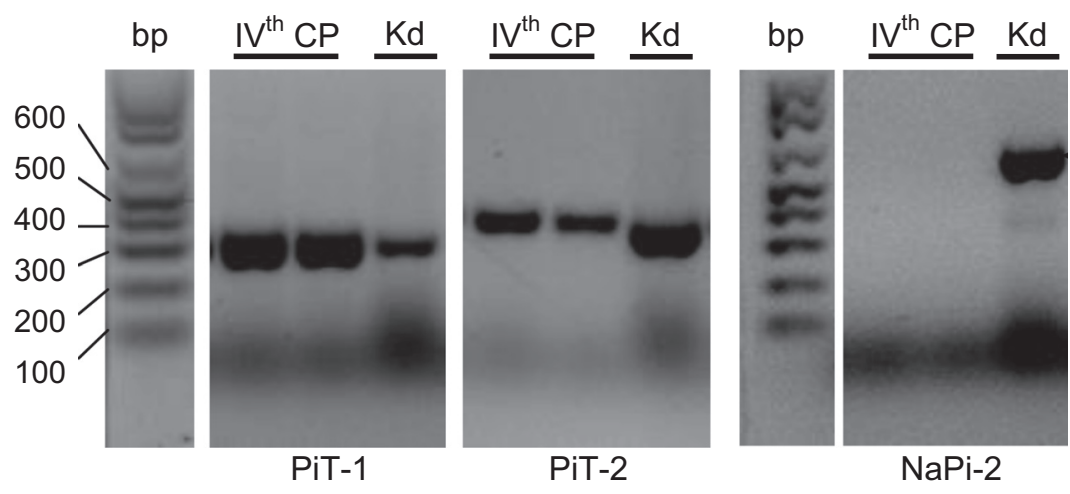

AJP-Renal Physiol $\bullet$ doi:10.1152/ajprenal.00458.2013 • www.ajprenal.org

Downloaded from www.physiology.org/journal/ajprenal (194.210.252.053) on April 4, 2019. 

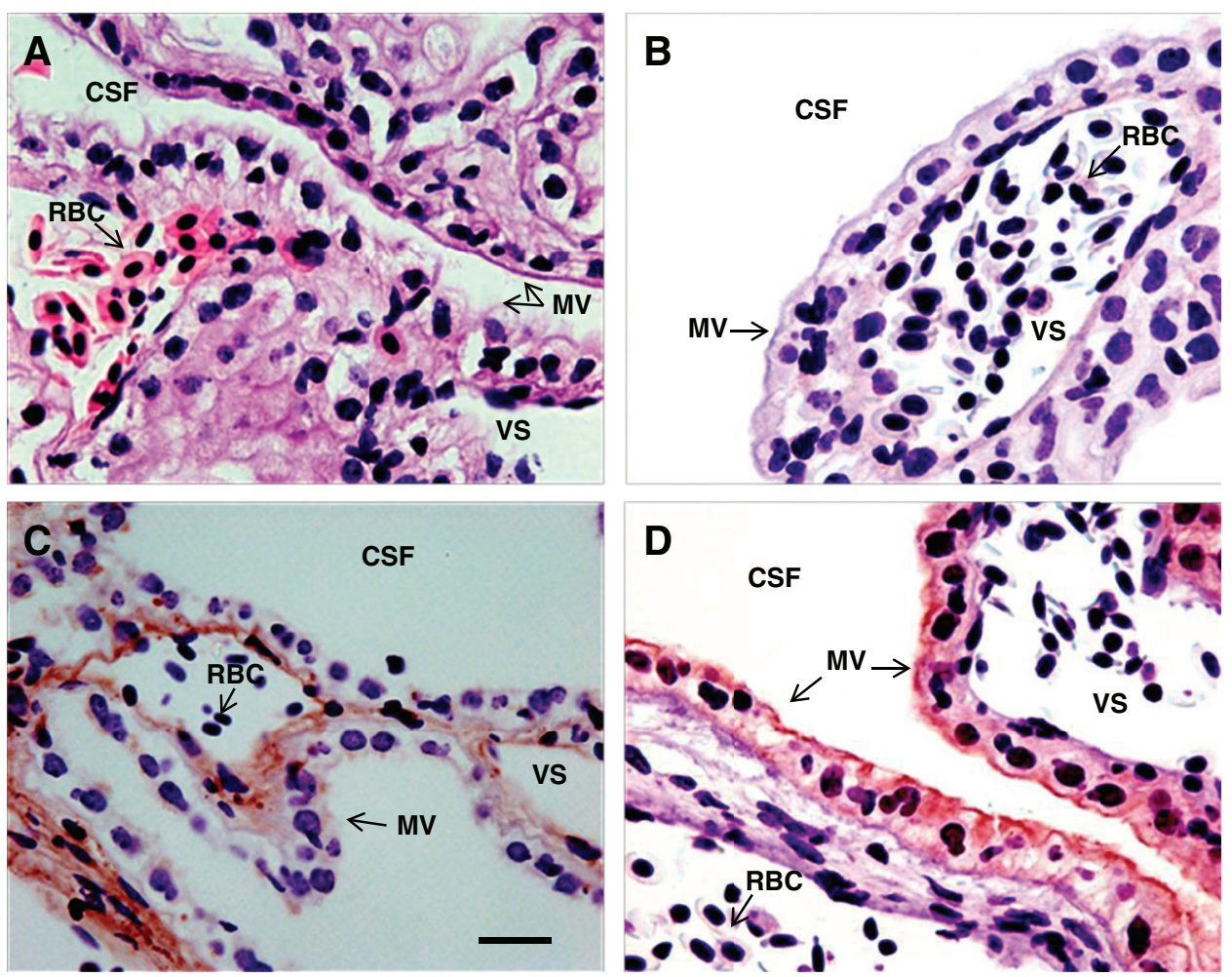

Fig. 4. Immunohistochemistry of paraffin-embedded spiny dogfish shark CPs. A: hematoxylin and eosin stain. $B$ : isotype for PiT1 and PiT2 showing no nonspecific staining. $C$ : PiT1 $(1: 1,600)$ showing light staining in the vascular endothelium. $D$ : PiT2 $(1: 1,000)$ showed heavier staining localized to the apical membrane region. CSF, ventricular location of CSF; RBC, nucleated shark red blood cells; $\mathrm{MV}$, microvilli of apical surface; VS, intravascular space. Scale bar $=25 \mu \mathrm{m}$.

ventricle and $\mathrm{CP}$ of the spiny dogfish shark as well as its suitability for Ussing chamber work make the determination of active $\mathrm{P}_{\mathrm{i}}$ transport relatively certain. With the $\mathrm{CP}$ epithelia chemically and electrically short circuited, the $\mathrm{P}_{\mathrm{i}}$ flux ratios were as high as 30:1. The in vitro transepithelial potential was about $+1 \mathrm{mV}$, ventricular side positive, with identical, proteinfree ER solution on each side. This is consistent with the earlier measurements of +2 to $+4 \mathrm{mV}$ also done in Ussing chambers (23). The mammalian transepithelial potential determined in vivo is also +2 to $+7 \mathrm{mV}$, CSF side positive (14).

Several of the criteria we used to categorize the active $P_{i}$ transport process were based on heterologous expression systems for SLC20 and SLC34 gene families (36). The five $\mathrm{P}_{\mathrm{i}}$ transporters known to participate in $\mathrm{P}_{\mathrm{i}}$ uptake by mammalian tissues capable of transepithelial $\mathrm{P}_{\mathrm{i}}$ transport are PiT1, PiT2,
NaPiIIa, NaPiIIb, and NaPiIIc. Distinctive features include the following: 1) all are $\mathrm{Na}^{+}$symporters and competitively inhibited by arsenate; 2) PFA blocks NaPiII types much more effectively than PiT types; 3) only NaPiIIc is electroneutral; 4) $\mathrm{Li}^{+}$, in the complete absence of $\mathrm{Na}^{+}(2)$, can drive transport on the PiT types but not NaPiII types; and 5) PiT-type proteins preferentially transport the monovalent form $\mathrm{H}_{2} \mathrm{PO}_{4}^{-}$, whereas NaPiII type proteins all preferentially transport $\mathrm{HPO}_{4}^{2-}$.

Arsenate is commonly used to inhibit $\mathrm{P}_{\mathrm{i}}$ transport in numerous assays (see Ref. 32) and, as a $\mathrm{P}_{\mathrm{i}}$ analog, interacts relatively effectively with $\mathrm{NaPiIIa}$, NaPiIIb, and NaPiIIc as well as with PiT1 and PiT2, but with much lower affinity than $\mathrm{P}_{\mathrm{i}}$. Although TER was unchanged by arsenate treatment, general metabolic effects may have contributed to the inhibition of transport; nevertheless, the arsenate effect
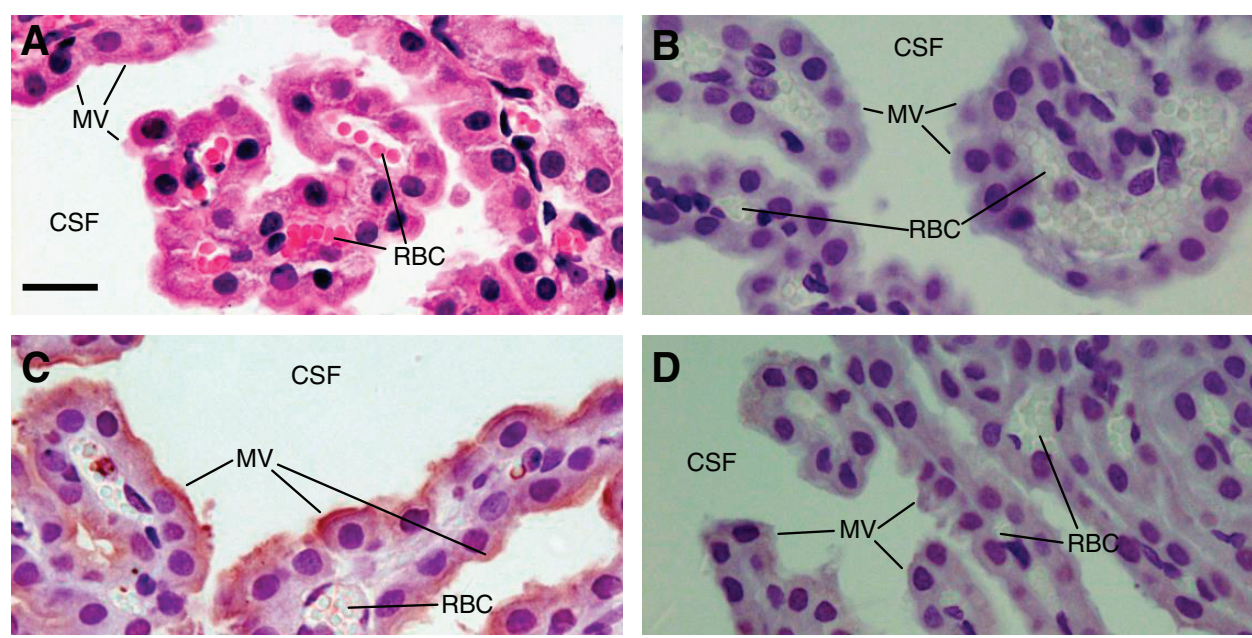

Fig. 5. Immunohistochemistry of parafifinembedded rat lateral CPs. A: hematoxylin and eosin stain. $B$ : isotype control for goat nonimmune IgG. $C$ : rat lateral CP stained with goat anti-human PiT2 antibody. D: rat lateral CP stained with goat anti-human PiT2 antibody in the presence of blocking antigen. Scale bar $=25 \mu \mathrm{m}$. 


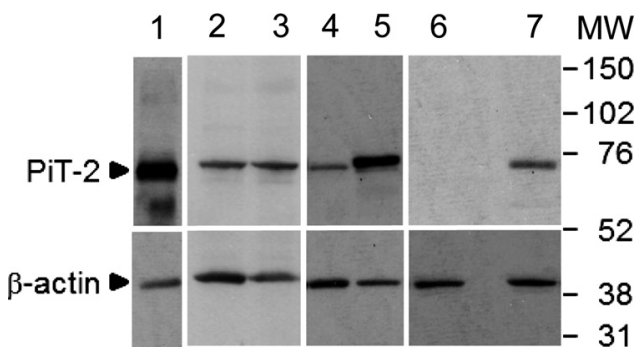

Fig. 6. A representative immunoblot of PiT2 in the dogfish IVth $\mathrm{CP}$ and lateral $\mathrm{CP}$ and rat lateral $\mathrm{CP}$. The single band at $\sim 70 \mathrm{kDa}$ (top) was coincident with the published PiT2 protein amino acid sequence in the rat. The lower band (bottom) indicates the presence of $\beta$-actin $(\approx 42 \mathrm{kDa})$. Bands were made visible using either goat anti-rabbit peroxidase-conjugated secondary antibody (lanes 1-5) or donkey anti-goat peroxidase-conjugated secondary antibody (lanes 6 and 7). Lane 1, shark IVth $\mathrm{CP}$ stained with rabbit anti-human antibody HPA026540 (Sigma); lanes 2 and 3, shark IVth CP and shark lateral $\mathrm{CP}$, respectively, stained with rabbit anti-rat antibody (gift of Dr. Sorribas); lanes 4 and 5, shark and rat lateral CPs, respectively, stained with rabbit anti-rat antibody (gift of Dr. Sorribas); lanes 6 and 7, rat lateral CPs stained with goat anti-human antibody (Santa Cruz Biotechnology) in the presence and absence of blocking antigen, respectively.

observed was consistent with facilitation of $\mathrm{P}_{\mathrm{i}}$ transport by specific transporters.

The active transepithelial transport reported here was dramatically, and reversibly, influenced by the cellular $\mathrm{K}^{+}$gradient, consistent with a reversible plasma membrane depolarization and arguing against electroneutral transport (NaPiIIc-like). The lack of effect of PFA at $1 \mathrm{mM}$ on net $\mathrm{P}_{\mathrm{i}}$ transport by the $\mathrm{CP}$ is consistent with PiT-type transport and the fact that we detected no NaPiII gene expression there. Phosphonocarboxylic acids, including PFA, are effective inhibitors of $\mathrm{P}_{\mathrm{i}}$ uptake by renal brush-border membrane vesicles $(26,39)$, where NaPiII transporters predominate; however, they have no effect on PiT1 or PiT2 when these transporters are overexpressed in oocytes (26) or in vascular smooth muscle cells at $1 \mathrm{mM}$ and inhibited only $47 \%$ even at $10 \mathrm{mM}(31)$.

Early work showed no significant driving ability by a $\mathrm{Li}^{+}$ gradient on $\mathrm{NaPiII}(3,36)$, and although more recent work has indicated that $\mathrm{Li}^{+}$does appear to have a very low potential to drive NaPiII phosphate transport, this cation interacts much more readily with PiT types than with NaPiII types. Work on rat vascular smooth muscle PiT1 and PiT2 has indicated that $\mathrm{Li}^{+}$will support $\sim 5 \%$ of the PiT1 phosphate transport capacity seen with normal $\left[\mathrm{Na}^{+}\right]$and $\sim 12 \%$ of PiT2 transport (31). In the present study, $\mathrm{Li}^{+}$, in the complete absence of $\mathrm{Na}^{+}$, drove almost one-half of $\mathrm{Na}^{+}$-dependent phosphate transport, adding support for a significant role of PiT types in CP active $\mathrm{P}_{\mathrm{i}}$ transport.

The degenerate primers used for the detection of NaPiIIb isoforms, the only known type II transporters in the shark, gave no evidence that these genes were expressed in the CP even though a strong signal was present in kidney samples. This does not rule out the presence of type II transporters in the $\mathrm{CP}$, but it is consistent with the PiT-like transport data. Furthermore, immunolocalization indicated that PiT2 is appropriately positioned in the tissue to move $\mathrm{P}_{\mathrm{i}}$ in the CSF-to-blood direction. The extent of heterologous antibody specificity and unknown tissue-specific antigenicity notwithstanding, there is a high degree of sequence conservancy in PiT2 across phyla, and, together with the PCR gene expression data, the present findings strongly indicate that the molecular correlate of transepithelial $\mathrm{P}_{\mathrm{i}}$ transport by $\mathrm{CP}$ is PiT2.

It is possible that part of the control of $\left[\mathrm{P}_{\mathrm{i}}\right]_{\mathrm{CSF}}$ may reside in the BBB. An anion exchange process in the BBB (or associated glia) may have an important contribution to the buffering capacity of the extracellular compartment of the brain (24), and studies $(9,10)$ on isolated BBB capillaries revealed a $\mathrm{P}_{\mathrm{i}} / \mathrm{HCO}_{3}^{-}$ exchange process. The influence of the $\mathrm{BBB}$ on $\left[\mathrm{P}_{\mathrm{i}}\right]$ in ISF could impact CSF through drainage of ISF across the ependymal lining of the ventricles. A hypothetical model incorporating a possible source (BBB via the ISF) and exit pathway for $P_{i}$ is shown in Fig. 7.

The overall structure of the $\mathrm{P}_{\mathrm{i}}$-transporting motif in the ubiquitously expressed SLC20 family has remained virtually unchanged during evolution, leading to the idea that PiTs generally fulfill housekeeping roles in cellular $\mathrm{P}_{\mathrm{i}}$ homeostasis (7). There is also evidence for specific functional roles in bone mineralization and cell proliferation (PiT1) as well as $\left[\mathrm{P}_{\mathrm{i}}\right]-$ sensitive and $\mathrm{pH}$-sensitive renal reabsorption (PiT2) (18). Interestingly, the modification of PiT2 caused by changing $\left[\mathrm{P}_{\mathrm{i}}\right]$ seems to be independent of its transport capability and suggests an involvement in $\mathrm{P}_{\mathrm{i}}$ sensing (29).

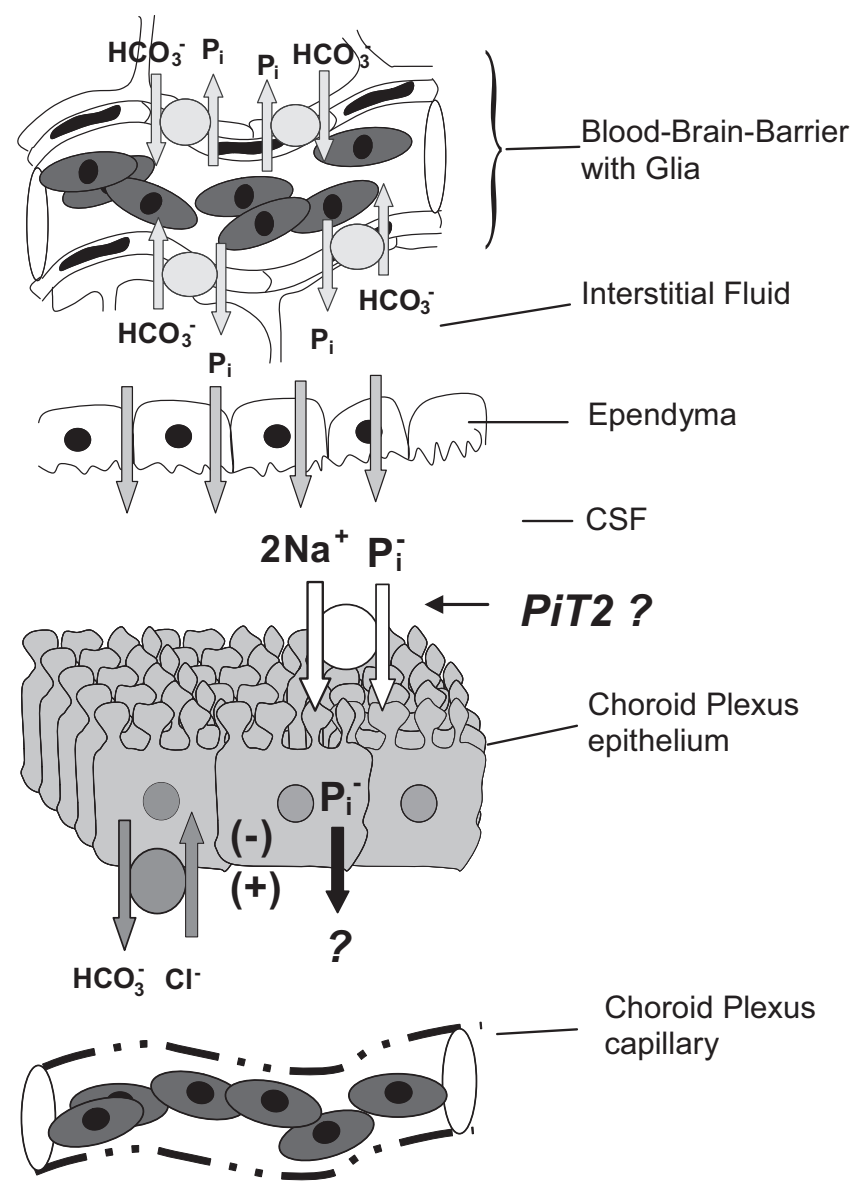

Fig. 7. The tissues that form and define CSF are shown in this hypothetical model of $\mathrm{P}_{\mathrm{i}}$ entry and exit. $\mathrm{P}_{\mathrm{i}}$ may enter interstitial fluid via the blood-brain barrier in exchange for $\mathrm{HCO}_{3}^{-}$(9). The interstitial fluid presumably mixes with CSF by bulk flow through the ependymal lining of the ventricles, which generally lack tight junctions, adding $\mathrm{P}_{\mathrm{i}}$ to CSF. The CP epithelium is hypothesized to use PiT2 in the apical microvilli to actively transport $\mathrm{P}_{\mathrm{i}}$ into the cell and then to the CP interstitium, by unknown processes, where it is carried away by the highly fenestrated CP capillaries. 
Perspectives. Because of the role of $\mathrm{P}_{\mathrm{i}}$ in vital cellular activities, perturbation of $\left[\mathrm{P}_{\mathrm{i}}\right]_{\mathrm{CSF}}$ may have notable physiological consequences, such as energy stress, an important pathogenic consequence in many neurodegenerative diseases (19). Low $\left[\mathrm{P}_{\mathrm{i}}\right]$ can cause membrane fragility and central nervous system dysfunction (18), whereas high $\left[\mathrm{P}_{\mathrm{i}}\right]$ in the extracellular fluid can stimulate an increased expression of PiT1 and PiT2, which may be related to increased calcium phosphate deposition in soft tissues (38), including the basal ganglia, where mutations in SCL20A2 are linked to disturbed regional phosphate homeostasis (Fahr disease) (37). On the other hand, after excitotoxicity or oxidative stress, high extracellular $\mathrm{P}_{\mathrm{i}}$ increases neuronal survival (13). Understanding the mechanisms responsible for the control of $\left[\mathrm{P}_{\mathrm{i}}\right]_{\mathrm{CSF}}$ could have significance beyond immediate metabolic status of neurons and glia. The acid-base buffering capacity of CSF, for example, is minimal, and at the $\mathrm{pH}$ of $\mathrm{CSF}, \mathrm{P}_{\mathrm{i}}$ is a nearly ideal buffer system; therefore, keeping $\left[\mathrm{P}_{\mathrm{i}}\right]_{\mathrm{CSF}}$ low may help maintain a high sensitivity to small shifts in $\mathrm{CO}_{2}$ and $\left[\mathrm{HCO}_{3}^{-}\right]$in CSF. In humans, a downward shift of CSF pH by only 0.05 units can cause a 10 -fold increase in breathing rate (27). Another $\mathrm{pH}^{-}$ related implication of regulation by PiT2 is that the $\mathrm{H}_{2} \mathrm{PO}_{4}^{-}$ substrate availability will be significantly impacted by small shifts in CSF $\mathrm{pH}$. Whether one considers shark CSF, with a $\mathrm{pH}$ of $\sim 7.8$ and $\left[\mathrm{P}_{\mathrm{i}}\right]$ of $0.6 \mathrm{mM}$, or mammalian CSF, with a $\mathrm{pH}$ of $\sim 7.2$ and $\left[\mathrm{P}_{\mathrm{i}}\right]$ of $0.4 \mathrm{mM},\left[\mathrm{H}_{2} \mathrm{PO}_{4}^{-}\right]$is in the range of $50-60$ $\mu \mathrm{M}$ and is not far from the $\mathrm{P}_{\mathrm{i}} K_{\mathrm{m}}$ of PiT2 reported for rats (25 $\mu \mathrm{M})$, mice $(38 \mu \mathrm{M})$, and humans $\left(K_{0.5} \sim 160 \mu \mathrm{M}\right)$ (see Ref. 6). Finally, in vivo experiments in rats have indicated that changes in $\left[\mathrm{P}_{\mathrm{i}}\right]_{\mathrm{CSF}}$ may have rapid and dramatic effects on renal $\mathrm{P}_{\mathrm{i}}$ excretion and on $P_{i}$ appetite (21). Thus, the process we describe here for the removal of CSF $\mathrm{P}_{\mathrm{i}}$ may be an important aspect of $\mathrm{P}_{\mathrm{i}}$, and $\mathrm{Ca}^{2+}$, homeostasis. Whereas a specific $\mathrm{Ca}^{2+}$-sensing receptor has been identified, and its roles in the maintenance of stable systemic $\mathrm{Ca}^{2+}$ levels and in hormone secretion have been well characterized, a similar $\mathrm{P}_{\mathrm{i}}$-sensing mechanism has not been described. Changes in $\left[\mathrm{P}_{\mathrm{i}}\right]$ can produce changes in PiT2 activity that seem to be due to structural changes, not the amount of PiT2 in the membrane (28). The active state of PiT2 is reported to involve assembly of oligomers in response to extracellular $\mathrm{P}_{\mathrm{i}}$ deprivation. In a bone cell line, this heightened activity can increase intracellular $\left[\mathrm{P}_{\mathrm{i}}\right]$ and decrease cAMP (22). PiT2 activity is also modulated by PKC- $\varepsilon$ (17). Thus, choroidal epithelial PiT2 could be part of a $\mathrm{P}_{\mathrm{i}}$-sensing/regulatory pathway analogous to the signaling axis proposed for intestinal phosphate modulation of renal $\mathrm{P}_{\mathrm{i}}$ reabsorption (5).

\section{ACKNOWLEDGMENTS}

The authors gratefully acknowledge the assistance of Michelle Bailey with animal care and maintenance, Alice R. Villalobos and Robin K. Young for advice and use of equipment, and Denise Long for troubleshooting the immunohistochemical analyses.

\section{GRANTS}

This work was supported by National Science Foundation Grant 0843253 and Fundação para a Ciência e a Tecnologia, Portugal.

\section{REFERENCES}

1. Abbott NJ. Evidence for bulk flow of brain interstitial fluid: significance for physiology and pathology. Neurochem Int 45: 545-552, 2004.

2. Andrini O, Meinild AK, Ghezzi C, Murer H, Forster IC. Lithium interactions with $\mathrm{Na}^{+}$-coupled inorganic phosphate cotransporters: in- sights into the mechanism of sequential cation binding. Am J Physiol Cell Physiol 302: C539-C554, 2012.

3. Bacconi A, Virkki LV, Biber Murer H Jr, Forster IC. Renouncing electroneutrality is not free of charge: switching on electrogenicity in a $\mathrm{Na}^{+}$-coupled phosphate cotransporter. Proc Natl Acad Sci USA 102: 12606-12611, 2005

4. Barshes N, Demopoulos A, Engelhard HH. Anatomy and physiology of the leptomeninges and CSF space. Cancer Treat Res 125: 1-16, 2005.

5. Berndt T, Thomas LF, Craig TA, Sommer S, Li X, Bergstralh EJ, Kumar R. Evidence for a signaling axis by which intestinal phosphate rapidly modulates renal phosphate reabsorption. Proc Natl Acad Sci USA 104: 11085-11090, 2007.

6. Bøttger P, Hede SE, Grunnet M, Høyer B, Klaerke DA, Pedersen L. Characterization of transport mechanisms and determinants critical for $\mathrm{Na}^{+}$-dependent $\mathrm{P}_{\mathrm{i}}$ symport of the PiT family paralogs human PiT1 and PiT2. Am J Physiol Cell Physiol 291: C1377-C1387, 2006.

7. Bøttger P, Pedersen L. Evolutionary and experimental analyses of inorganic phosphate transporter PiT family reveals two related signature sequences harboring highly conserved aspartic acids critical for sodiumdependent phosphate transport function of human PiT2. FEBS $J$ 272: 3060-3074, 2005.

8. Brazy PC, Gullans SR, Mandel LJ, Dennis VW. Metabolic requirement for inorganic phosphate by the rabbit proximal tubule. J Clin Invest 70 : 53-62, 1982.

9. Dallaire L, Beliveau R. Phosphate transport by capillaries of the bloodbrain barrier. J Biol Chem 267: 22323-22327, 1992.

10. Dallaire L, Giroux S, Beliveau R. Regulation of phosphate transport by second messengers in capillaries of ythe blood-brain barrier. Biochim Biophys Acta 1110: 59-64, 1992.

11. Fishman RA. Cerebrospinal Fluid in Diseases of the Nervous System. Philadelphia, PA: Saunders, 1992, p. 431.

12. Gilbert PW, Mathewson RF, Rall DP. Sharks, Skates and Rays. Baltimore, MD: The Johns Hopkins Press, 1967, p. 624.

13. Glinn M, Ni B, Irwin RP, Kelley SW, Lin SZ, Paul SM. Inorganic $P_{i}$ increases neuronal survival in the acute early phase following excitotoxic/ oxidative insults. J Neurochem 70: 1850-1858, 1998.

14. Held D, Fencl V, Pappenheimer JR. Electrical potential of cerebrospinal fluid. J Neurophysiol 27: 942-959, 1964.

15. Javaheri S, Weyne J, Demeester G, Leusen I. Effects of acetazolamide on ionic composition of cisternal fluid during acute respiratory acidosis. $J$ Appl Physiol 57: 85-91, 1984.

16. Javaheri S, Weyne J, Demeester G, Leusen I. Effects of SITS, an anion transport blocker, on CSF ionic composition in metabolic alkalosis. J Appl Physiol 57: 92-97, 1984.

17. Jobbagy Z, Olah Z, Petrovics G, Eiden MV, Leverett BD, Dean NM, Anderson WB. Up-regulation of the Pit-2 phosphate transporter/retrovirus receptor by protein kinase C epsilon. J Biol Chem 274: 7067-7071, 1999.

18. Khoshniat S, Bourgine A, Julien M, Weiss P, Guicheuxm Jr, Beck L. The emergence of phosphate as a specific signaling molecule in bone and other cell types in mammals. Cell Mol Life Sci 68: 205-218.

19. Mandemakers W, Morais VA, De Strooper B. A cell biological perspective on mitochondrial dysfunction in Parkinson disease and other neurodegenerative diseases. J Cell Sci 120: 1707-1716, 2007.

20. Moody DM. The blood-brain barrier and blood-cerebral spinal fluid barrier. Semin Cardiothorac Vasc Anesth 10: 128-131, 2006.

21. Mulroney SE, Woda CB, Halaihel N, Louie B, McDonnell K, Schulkin J, Haramati A, Levi M. Central control of renal sodium-phosphate (NaPi-2) transporters. Am J Physiol Renal Physiol 286: F647-F652, 2004.

22. Naviglio S, Spina A, Chiosi E, Fusco A, Illiano F, Pagano M, Romano M, Senatore G, Sorrentino A, Sorvillo L, Illiano G. Inorganic phosphate inhibits growth of human osteosarcoma U2OS cells via adenylate cyclase/ cAMP pathway. J Cell Biochem 98: 1584-1596, 2006.

23. Patlak CSAR, Oppelt WW, Rall DP. Potential differences of the ventricular fluid in vivo and in vitro in the dogfish. Life Sci 5: 2011-2015, 1966.

24. Portman MA, Lassen NA, Cooper TG, Sills AM, Potchen EJ. Intraand extracellular $\mathrm{pH}$ of the brain in vivo studied by ${ }^{31} \mathrm{P}-\mathrm{NMR}$ during hyper- and hypocapnia. J Appl Physiol 71: 2168-2172, 1991.

25. Rall DP, Sheldon W. Transport of organic acid dyes by the isolated choroid plexus of the spiny dogfish, S. acanthias. Biochem Pharmacol 11: $169-170,1962$. 
26. Ravera S, Virkki LV, Murer H, Forster IC. Deciphering PiT transport kinetics and substrate specificity using electrophysiology and flux measurements. Am J Physiol Cell Physiol 293: C606-C620, 2007.

27. Rhoades RA, Bell DR. Medical Physiology. Baltimore, MD: Lippincott, Williams \& Wilkins, 2013, p. 819.

28. Rodrigues P, Heard JM. Modulation of phosphate uptake and amphotropic murine leukemia virus entry by posttranslational modifications of PIT-2. J Virol 73: 3789-3799, 1999.

29. Salaun C, Marechal V, Heard JM. Transport-deficient PiT2 phosphate transporters still modify cell surface oligomers structure in response to inorganic phosphate. J Mol Biol 340: 39-47, 2004.

30. Terryn S, Jouret Fo, Vandenabeele F, Smolders I, Moreels M, Devuyst $\mathbf{O}$, Steels $\mathbf{P}$, Kerkhove EV. A primary culture of mouse proximal tubular cells, established on collagen-coated membranes. Am J Physiol Renal Physiol 293: F476-F485, 2007.

31. Villa-Bellosta R, Bogaert YE, Levi M, Sorribas V. Characterization of phosphate transport in rat vascular smooth muscle cells. Arterioscler Thromb Vasc Biol 27: 1030-1036, 2007.

32. Villa-Bellosta R, Sorribas V. Arsenate transport by sodium/phosphate cotransporter type IIb. Toxicol Appl Pharmacol 247: 36-40, 2010.

33. Villa-Bellosta R, Sorribas V. Different effects of arsenate and phosphonoformate on $\mathrm{P}_{\mathrm{i}}$ transport adaptation in opossum kidney cells. Am J Physiol Cell Physiol 297: C516-C525, 2009.
34. Villalobos ARA, Miller DS, Renfro JL. Transepithelial organic anion transport by shark choroid plexus. Am J Physiol Regul Integr Comp Physiol 282: R1308-R1316, 2002.

35. Villalobos ARA, Renfro JL. Trimethylamine oxide suppresses stressinduced alteration of organic anion transport in choroid plexus. J Exp Biol 210: 541-552, 2007

36. Virkki LV, Biber J, Murer H, Forster IC. Phosphate transporters: a tale of two solute carrier families. Am J Physiol Renal Physiol 293: F643F654, 2007.

37. Wang C, Li Y, Shi L, Ren J, Patti M, Wang T, de Oliveira JR, Sobrido MJ, Quintans B, Baquero M, Cui X, Zhang XY, Wang L, Xu H, Wang J, Yao J, Dai X, Liu J, Zhang L, Ma H, Gao Y, Ma X, Feng S, Liu M, Wang QK, Forster IC, Zhang X, Liu JY. Mutations in SLC20A2 link familial idiopathic basal ganglia calcification with phosphate homeostasis. Nat Genet 44: 254-256, 2012.

38. Wittrant Y, Bourgine A, Khoshniat S, Alliot-Licht B, Masson M, Gatius M, Rouillon T, Weiss P, Beck L, Guicheux J. Inorganic phosphate regulates Glvr-1 and -2 expression: Role of calcium and ERK1/2. Biochem Biophys Res Comm 381: 259-263, 2009.

39. Yusufi ANK, Szczepanska-Konkel M, Kempson SA, McAteer JA, Dousa TP. Inhibition of human renal epithelial $\mathrm{Na}+/ \mathrm{Pi}$ cotransport by phosphonoformic acid. Biochem Biophys Res Comm 139: 679-686, 1986.

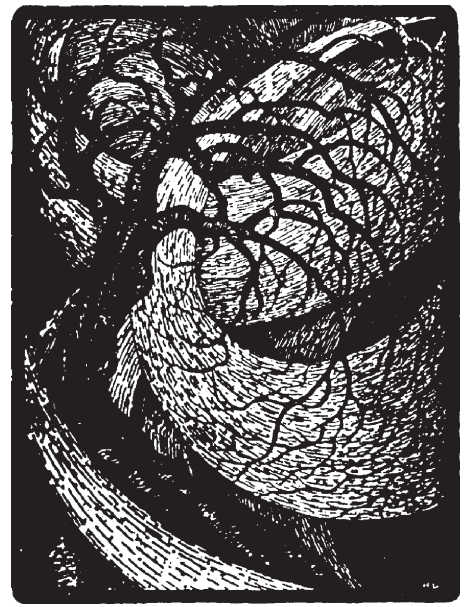

